\title{
Predicting Performance through the Elements of Organizational Culture
}

\author{
1Ibidunni, Olanrewaju Samson, ${ }^{2}$ Agboola Gbenga Mayowa \\ Department of Business Management, College of Business \& Social Sciences, \\ Covenant University, Canaanland, Ota, Ogun-State, Nigeria. \\ ${ }^{1}$ gbenga.agboola@covenantuniversity.edu.ng \\ ${ }^{2}$ samson.ibidunning@covenantuniversity.edu.ng
}

\begin{abstract}
Organizational culture is shaped by the leaders and by the purpose for which the organization exist. There are many cultures and sub-cultures, which may be of different strengths and which may have different levels of influence. The main aim of this paper was to determine what elements of organizational culture predict the performance of an organization. The objectives of the study were to determine if the different elements of organizational culture has significant contribution on the performances of Universities and to reveal which of the different elements of organizational culture has the most significant contribution in predicting the performances of Universities. To determine what elements of organizational culture predict the performance of an organization, a sample of 100 staff (academic and non-academic)each of Covenant University, Ota, Olabisi Onabanjo University, Ago-Iwoye, University of Agriculture, Abeokuta, all in Ogun State were drawn. Data was collected with the use of a Likert type questionnaire and were analyzed using multiple regressions with the aid of Statistical Package for Social Sciences (SPSS). The finding shows that Quality Consciousness, Role Clarity, Employee Concern, Customer Care and Code of Conduct made the most significant contribution in predicting performances of organizations. Conclusively, there is no such thing as a 'right' or 'best' culture for all organizations. The most appropriate culture for an organization is the one that best helps it cope with the exigencies of its business environment. The most appropriate culture for an organization is the one that best helps it cope with the exigencies of its business environment.
\end{abstract}

Key words: Organizational Culture, Elements of Organizational Culture, Predicting and Organizational Performance

\section{INTRODUCTION:}

In the beginning nal culture is shaped by the leaders and by the purpose for which the organization has been created. It then develops within the constraints of the environment, technology, values of the leadership, and performance expectations. "The initial culture is altered by the design variables of the organization, experiences of the organization, management's leadership style, the structure of the organization, the nature of the tasks of the groups, the way decisions are made, and the size of the organization. In addition, the developing culture is affected by the internal integrity of the organization, the climate, and how well the organization is competing in the marketplace, its effectiveness" DeWitt (2001).

Culture generates strong pressures on people to go along, to think and act in ways consistent with the way employees dress and the amount of time allowed to elapse before meetings begin, to the speed with which people are promoted. 
Although, it is a known fact that culture has an effect on people's behaviour, management's interest is likely to be prompted by curiosity about why this happens than by its possible bottom-line effects on the commercial performance of an organization. To a large extent this interest was kindled by the writings of authors who view culture as a key component in the performance of successful organizations. These ideas resulted in an increased awareness among managers of the effects of culture but, as is often the case, a more dangerous turn of events were set in motion.

When cultural characteristics of successful organizations were set out in books in a catchy, marketable and easily grasped way, there was an understandable tendency for some managers to believe that, at last, social science had come up with something of immense practical use. Other than the writings of popular authors, there is little evidence of a strong association between culture and organizational performance, and none for a set of cultural characteristics that are likely to be appropriate in all circumstances.

Later, when studies were conducted on firms that were said to have their culture associated with performance, no coherent link between culture and performance could be established and several of the firms were in serious difficulties.

\section{CONCEPTUAL FRAMEWORK:}

Organizational culture is the basic pattern of shared assumptions, values and beliefs considered to be correct way of thinking about and acting on problems and opportunities facing the organization. McShane (2005) simply describes organizational culture as an organization's DNA not visible to the eye, but a very powerful tool that shapes what happens in an organization.

Mowat (2002) put forward that organizational culture is the personality of the organization: the shared beliefs, values and behaviours of the group. It is symbolic, holistic, and unifying, stable, and difficult to change. Organizational culture is made up of both the visible and invisible, conscious and unconscious learning and artifacts of an organization. Mowat also said that culture is the shared mental model that is assumptions. This mental model that is assumptions are taken for granted by those within the organization and it is difficult for people outside the organization to decode it. It is important to note therefore that the organizational culture is not the ideal, vision, and mission stated for the organization towards achieving its goals and objectives, rather, it is the expression of the day-to-day practices, communications, norms, values and beliefs that exist within an organization.

According to Borgatti (1996) a strong culture:

- Is internally consistent

- Is widely shared, and

- Makes it clear what appropriate behaviour is.

The result of an organization with a vision that everyone understands to which everyone is committed to, When employees gather and particularly when employees with a common purpose begin to work together, the strategies of work and the processes of thinking will enlarge and the culture of the organization will be created. No organization exist in a vacuum just as we know that "no man is an island," most organizational cultures have key features that are common with the larger culture of the community or society in which the organization exist. For example in Mowat (2002), organizational cultures in America all have some similar underlying thread. Organizational cultures in other countries also have a unifying, crossorganizational flavour. However, even within a social culture, each organizational culture is unique. 
Put more simply, organizational culture is the way things are getting done in an organization. It is what determines the action in an organization, guides how employees think, act and feel. It is the systematic set of assumptions that define day-to-day working behaviour. "Culture can be described in a circular fashion where philosophy expresses values; values are manifest in behaviour; and behaviour gives meaning to the underlying philosophy. Philosophy, values, and behaviour describe an organization's culture and culture is the glue that holds the organization together." DeWitt (2001)

Organizational culture can also be looked at as a system with inputs from the environment and outputs such as behaviours, technologies and products. It "is dynamic and fluid, and it is never static. A culture may be effective at one time, under a given set of circumstances and ineffective at another time. There is no generically good culture. There are however, generic patterns of health and pathology." Hagberg et al (2000).

According to BOLA (2001), culture is the shared beliefs, values and norms of a group and it includes:

- The way work is organized and experienced

- How authority exercised and distributed

- How people are and feel rewarded, organized and controlled

- The values and work orientation of staff

- The degree of formalization, standardization and control through systems there is/should be

- The value placed on planning, analysis, logic, fairness etc.

- How much initiative, risk-taking, scope for individuality and expression is given

- Rules and expectations about such things as informality in interpersonal relations, dress, personal eccentricity etc.

- Differential status

- Emphasis given to rules, procedures, specifications of performance and results, team or individual working

There are many cultures and sub-cultures, which may be of different strengths and which may have different levels of influence. "Subcultures may share certain characteristics, norms, values and beliefs or be totally different. These subcultures can function cooperatively or be in conflict with each other." Hagberg et al (2000).

The Organizational Culture Inventory (OCI) defines corporate culture as "the sum of all moral concepts reflecting direct and indirect behavioural expectations. The central question of the OCI is: How must an employee behave in order to match the organization and meet the expectations?"

There is considerable overall agreement as to the general definition of organizational culture and most questionnaires define culture as: "a set of cognitions shared by members of a social unit" O'Reilly et al (1991), or more fully: "a system of shared values and beliefs that produces norms of behaviour and establishes an organizational way of life" Koberg et al (1987). This latter definition is important because it pinpoints that the culture construct can be equivocally understood to deal with "major beliefs and values" Goll et al (1991), or alternatively as "norms and patterns of behaviours and norms" Gundry et al (1994).

Employees are influenced by multiple cultural institutions such as family, community, nation, state, church, educational system, and other work organizations, and these associations shape their attitudes, behaviour, and identity; employees bring these influences with them when they join an organization, so it is difficult to separate an organizational culture from the larger cultural processes (Hatch, 1997).According to the work of Koteswara, P. K., Srinivasan, P. T. 
and George J.P. (2005),Literatures have revealed that organizational culture have been measured by various authors in terms of various elements. Koteswara et al identified a total number of 123 elements from ten different authors in his work. This does not connote that there are only 123 elements of organizational culture that can be used to measure organizational culture; there is a possibility that there may be some more which have not fallen into the 123 elements. Koteswara and his colleagues went further to summarize the 123 elements into ten elements that can be used in the measurement of organizational culture, which include, unity in diversity, creativity-adaptability, culture nurturing, customer care, quality consciousness, collaboration, open communication, code of conduct, role clarity and employee concern.

The objectives under consideration in this paper was:

- To determine if the different elements of organizational culture has significant contribution on the performances of Universities.

- To reveal which of the different elements of organizational culture has the most significant contribution in predicting the performances of Universities.

\section{Research Question:}

a) Which of the elements of organizational culture has significant contribution on the performances of Universities?

b) Which of the elements of organizational culture has the most significant contribution in predicting the performances of Universities?

\section{Research Hypothesis:}

$\mathrm{H}_{0}$ : There is no significant contribution of the elements of organizational culture in predicting the performances of Universities.

$\mathrm{H}_{1}$ : There is significant contribution of the elements of organizational culture in predicting the performances of Universities.

\section{RESEARCH METHOD}

The method adopted in this study was the Survey Research Design, which is to research on "Predicting Performance through the Elements of Organizational Culture" using the questionnaire to harvest opinions on the culture and performances of Universities. The population studied cuts across all staff of the three Universities in Ogun State, Nigeria. The hierarchical structure of the study population is made up of three tiers, which include top, middle and lower level staff. The characteristic of the study population is that it was mixed at every level of the organization irrespective of age, sex, educational background, employment level, salary scale and marriage status.

The sample frame for this study covers all staff at various levels of the three Universities in Ogun State. The sample size, which was determined judgmentally, consisted of 100 staff of each of the Universities. Non-probability sampling technique was the sample technique adopted and the sampling instrument used was a structured questionnaire. The respondents to the questionnaire were selected based on convenience sampling in each of the Universities.

The Questionnaire was the data collecting instrument used in this study. The questionnaire had twenty major statements, which was intended to assess "Predicting Performance through the Elements of Organizational Culture" of three Universities in Ogun State, Nigeria. Twenty item statements of a five point Likert Scale ranging from a "Strongly Agree to Strongly Disagree", were asked to get responses on 10 elements of Organizational Culture, which are: Culture Nurturing, Creativity - Adaptability, Unity in Diversity, Customer Care, Collaboration, Open Communication, Code of Conduct, Role of Clarity, Quality Consciousness and Employee Concern; and responses on two Performance variables: Perceptions and Effectiveness. The 
questionnaire was a structured one as the method of data collection and field assistance was used in retrieving the questionnaires from the respondents.

The data from the questionnaires were collected, collated, sorted, analyzed and presented through the use of multiple regressions. The procedures for processing the data was done through the use of analytical software called the Statistical Package for Social Sciences (SPSS). All the items in the questionnaire were analyzed.

\section{RESULT}

This section of the paper presents the data collected on the "Likert scale," through the use of Multiple Regression. A frequency table was used for analysing the monthly salary of the respondents from the three Universities. After the data had been collected, the procedures for the processing of the collected data using Likert scale was through the use of analytical software called the SPSS. The hypothesis was tested using Multiple Regression.

Table 1: Frequency Distribution Table of Respondents by Monthly Salary from the three universities

\begin{tabular}{|c|c|c|c|c|c|c|}
\hline \multicolumn{3}{|c|}{ Universities } & \multirow{2}{*}{$\begin{array}{c}\text { Frequency } \\
19\end{array}$} & \multirow{2}{*}{$\begin{array}{c}\text { Percent } \\
23.2\end{array}$} & \multirow{2}{*}{$\begin{array}{c}\begin{array}{c}\text { Valid } \\
\text { Percent }\end{array} \\
26.4\end{array}$} & \multirow{2}{*}{$\begin{array}{c}\begin{array}{c}\text { Cumulative } \\
\text { Percent }\end{array} \\
26.4\end{array}$} \\
\hline Private (CU) & Valid & below - N49,999 & & & & \\
\hline & & N50,000 & 32 & 39.0 & 44.4 & 70.8 \\
\hline & & $\mathrm{N} 100,000$ & 17 & 207 & 236 & 94.4 \\
\hline & & N199,999 & & & & 94.4 \\
\hline & & N200,000 - Above & 4 & 4.9 & 5.6 & 100.0 \\
\hline & & Total & 72 & 87.8 & 100.0 & \\
\hline & Missing & System & 10 & 12.2 & & \\
\hline & Total & & 82 & 100.0 & & \\
\hline \multirow[t]{5}{*}{ State (OOU) } & Valid & below - N49,999 & 33 & 39.3 & 39.3 & 39.3 \\
\hline & & $\begin{array}{l}\mathrm{N} 50,000 \\
\mathrm{~N} 99,999\end{array}$ & 32 & 38.1 & 38.1 & 77.4 \\
\hline & & $\begin{array}{l}\mathrm{N} 100,000 \\
\mathrm{~N} 199,999\end{array}$ & 18 & 21.4 & 21.4 & 98.8 \\
\hline & & N200,000 - Above & 1 & 1.2 & 1.2 & 100.0 \\
\hline & & Total & 84 & 100.0 & 100.0 & \\
\hline \multirow[t]{7}{*}{ Federal (UNAAB) } & Valid & below - N49,999 & 19 & 24.7 & 25.7 & 25.7 \\
\hline & & $\begin{array}{l}\mathrm{N} 50,000 \\
\mathrm{~N} 99,999\end{array}$ & 21 & 27.3 & 28.4 & 54.1 \\
\hline & & $\begin{array}{l}\mathrm{N} 100,000 \\
\mathrm{~N} 199,999\end{array}$ & 20 & 26.0 & 27.0 & 81.1 \\
\hline & & N200,000 - Above & 14 & 18.2 & 18.9 & 100.0 \\
\hline & & Total & 74 & 96.1 & 100.0 & \\
\hline & Missing & System & 3 & 3.9 & & \\
\hline & Total & & 77 & 100.0 & & \\
\hline
\end{tabular}

The table 1 above, shows the total number of respondents' monthly salary and their percentages. It reveals that from CU, 23.2\% received the salary between below - N49,999 every month, 39.0\% received the salary between N50,000 - N99,999 every month, 20.7\% received the salary between N100,000 - N199,999 every month, 4.9\% received the salary between N200,000 - above every month and none were missing. From O0U, 39.3\% received the salary between below - N49,999 every month, 38.1\% received the salary between N50,000 - N99,999 every month, 21.4\% received the salary between N100,000 - N199,999 every month, 1.2\% received the salary between N200,000 - above every month and none were missing. From UNAAB, 24.7\% received the salary between below - N49,999 every month, $27.3 \%$ received the salary between N50,000 - N99,999 every month, $26.0 \%$ received the salary between N100,000 - N199,999 every month, 18.2\% received the salary between N200,000 above every month and $3.2 \%$ were missing. 


\section{TEST OF HYPOTHESIS}

The data from Covenant University (CU), Olabisi Onabanjo University (OOU) and University of Agriculture (UNAAB) were also combined and analyzed to determine the significant contribution of the elements of organizational culture in predicting the performances of the three Universities on general terms. The analysis of the three Universities combined is as presented below:

Table 2a: Model Summary for the three Universities (CU, OOU, and UNAAB)

\begin{tabular}{|c|c|c|c|c|}
\hline Model & R & R Square & $\begin{array}{c}\text { Adjusted R } \\
\text { Square }\end{array}$ & $\begin{array}{c}\text { Std. Error of } \\
\text { the Estimate }\end{array}$ \\
\hline 1 & $.659(\mathrm{a})$ & .434 & .409 & .49454 \\
\hline
\end{tabular}

Table 2b: ANOVA for the three Universities (CU, OOU, and UNAAB)

\begin{tabular}{|cc|c|c|c|c|c|}
\hline Model & & $\begin{array}{c}\text { Sum of } \\
\text { Squares }\end{array}$ & df & Mean Square & F & Sig. \\
\hline 1 & Regression & 41.700 & 10 & 4.170 & 17.050 & $.000(\mathrm{a})$ \\
& Residual & 54.295 & 222 & .245 & & \\
& Total & 95.995 & 232 & & & \\
\hline
\end{tabular}

Table 2c: Coefficients for the three Universities (CU, OOU, and UNAAB)

\begin{tabular}{|l|c|c|c|c|c|c|c|}
\hline \multirow{2}{*}{ Model } & \multicolumn{2}{|c|}{$\begin{array}{c}\text { Unstandardized } \\
\text { Coeffients }\end{array}$} & $\begin{array}{c}\text { Standardized } \\
\text { Coefficients }\end{array}$ & t & Sig. & \multicolumn{2}{c|}{$\begin{array}{c}\text { Collinearity } \\
\text { Statistics }\end{array}$} \\
\cline { 2 - 8 } & B & Std. Error & Beta & Tolerance & VIF & B \\
Brror \\
\hline 1 (Constant) & 3.675 & .262 & & 14.032 & .000 & & \\
i1A & .023 & .041 & .031 & .554 & .580 & .833 & 1.200 \\
Responses to Item 2 & .013 & .037 & .023 & .358 & .721 & .603 & 1.659 \\
i3A & .049 & .050 & .055 & .983 & .327 & .803 & 1.245 \\
Responses to Item 4 & .117 & .033 & .199 & 3.574 & .000 & .819 & 1.221 \\
Responses to Item 5 & -.104 & .031 & -.211 & -3.386 & .001 & .657 & 1.523 \\
Responses to Item 6 & -.038 & .034 & -.064 & -1.112 & .267 & .769 & 1.300 \\
Responses to Item 7 & -.018 & .031 & -.034 & -.593 & .554 & .761 & 1.315 \\
Responses to Item 8 & -.102 & .034 & -.177 & -2.984 & .003 & .726 & 1.378 \\
Responses to Item 9 & -.078 & .033 & -.145 & -2.348 & .020 & .669 & 1.495 \\
Responses to Item 10 & .130 & .030 & .251 & 4.267 & .000 & .734 & 1.362 \\
\hline
\end{tabular}

a. Dependent Variable: Performance

Key:

i1A: Unity in Diversity;

Item 2: Creativity - Adaptability;

Concern

i3A: Culture nurturing

Item 4: Customer Care
Item 5: Quality Consciousness

Item 6: Collaboration

Item 7: Open Communication

Item 8: Code of Conduct
Item 9: Role Clarity Item 10: Employee 


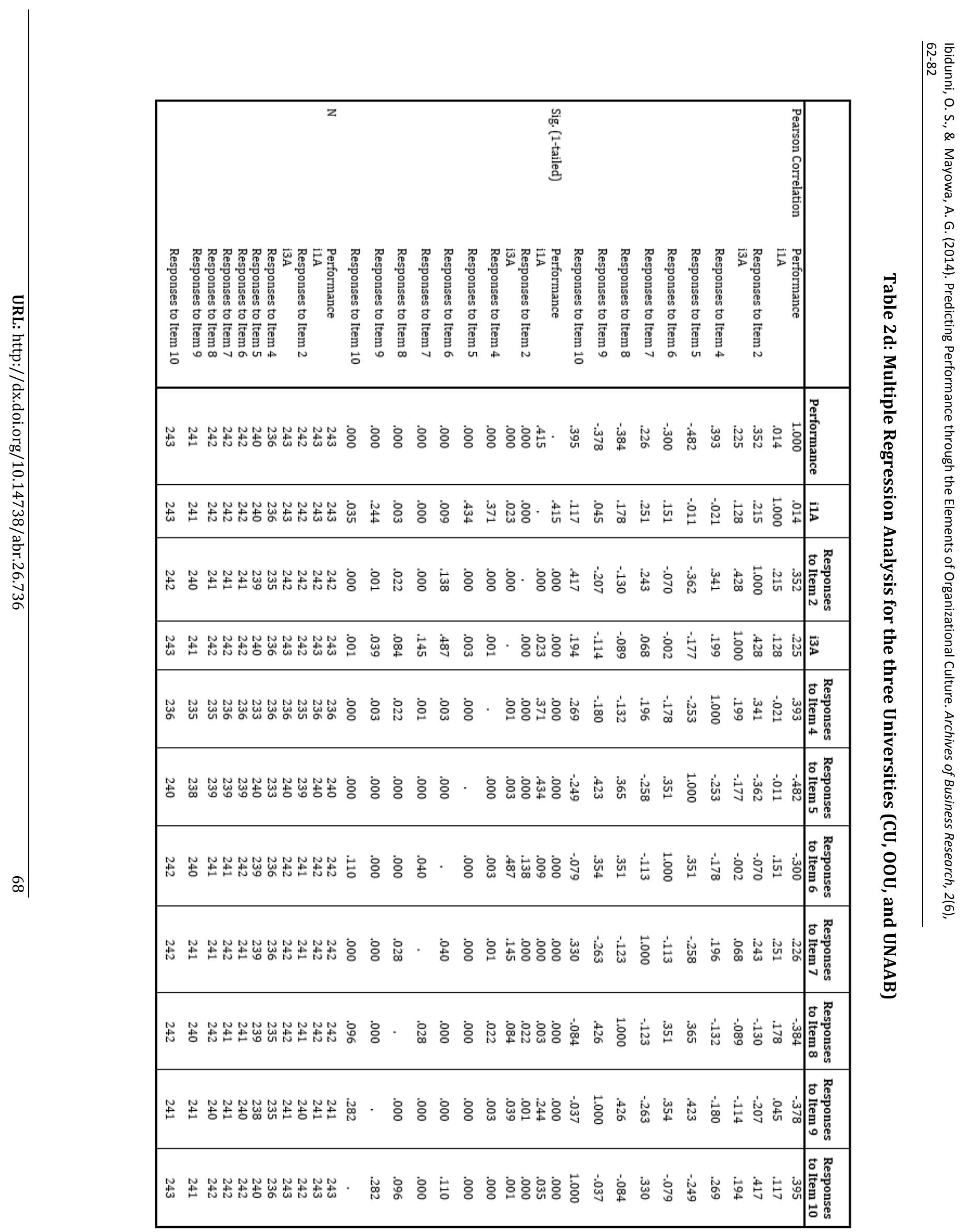


The above analysis is part of the results generated from the SPSS package using multiple regression analysis. The three Universities were investigated together as a whole. From the analysis, several tables were generated, but for the basis of measuring the significant contribution of each element of organizational culture in predicting performance, three tables will be used to explain the significant contribution of each of the elements of organizational culture on performance. These tables are model summary, correlation and coefficient.

In the multiple regression analysis table (Table $2 \mathrm{~d}$ ), the column showing $\mathrm{i} 1 \mathrm{~A}$, responses to item 2 , i3A, and responses item 4 to responses to item 10, represent each of the cultural element analyzed. From the analysis in table 4.9, items 2, 4, 5, 6, 8, 9 and 10, have moderately strong correlations with the dependent variable (Performance), which is equal to and above ".300". Also, the correlation among each of the independent variables is not too high. Researchers suggest that we do not include two variables with a bivariate correlation of ".7" or more in the same analysis.

In table 2a (model summary), the result shows how much of the variance in the dependent variable (Performance) is explained by the model, which includes the variable item 1 to 10 (the elements of organizational culture). The ".434" in the ' $R$ ' square column is expressed in percentage. This means that our model (the cultural elements) explains $43.4 \%$ of the variance on performances of the three Universities, which is a weak relationship.

In comparing the contribution of each independent variable (cultural elements), table 2c (coefficient table) will be used to determine this. In the "Beta" column, the largest value is considered, that is ".251" for item 10. This means that, the cultural element item 10 makes the strongest unique contribution in explaining the dependent variable (Performance). The Beta values for the other elements indicate that they made less contribution on performance. The "Sig." column of the same table shows, whether this variable is making a statistically significant unique contribution. The decision rule is that if the "Sig." value is less than .05, then the variable is making a statistically significant unique contribution on the dependent variable (Performance). Therefore, items 4, 5, 8, 9, and 10 made a statistically significant unique contribution on performances of the three Universities combined as a whole.

A further analysis was also done on each of the three Universities to check the significant contribution of the elements of organizational culture in predicting performance. The analysis below is a multiple regression analysis on Covenant University:

Table 3a: Model Summary for Covenant University (CU)

\begin{tabular}{|c|c|c|c|c|}
\hline Model & R & R Square & $\begin{array}{c}\text { Adjusted R } \\
\text { Square }\end{array}$ & $\begin{array}{c}\text { Std. Error of } \\
\text { the Estimate }\end{array}$ \\
\hline 1 & $.693(\mathrm{a})$ & .480 & .403 & .40667 \\
\hline
\end{tabular}

Table 3b: ANOVA for Covenant University (CU)

\begin{tabular}{|c|c|c|c|c|c|c|}
\hline Model & & $\begin{array}{c}\text { Sum of } \\
\text { Squares }\end{array}$ & df & Mean Square & $\mathbf{F}$ & Sig. \\
\hline \multirow[t]{3}{*}{1} & Regression & 10.368 & 10 & 1.037 & 6.269 & $.000(a)$ \\
\hline & Residual & 11.246 & 68 & .165 & & \\
\hline & Total & 21.614 & 78 & & & \\
\hline
\end{tabular}


Ibidunni, O. S., \& Mayowa, A. G. (2014). Predicting Performance through the Elements of Organizational Culture. Archives of Business Research, 2(6), $62-82$

Table 3c: Coefficients for Covenant University (CU)

\begin{tabular}{|c|c|c|c|c|c|c|c|}
\hline \multirow[t]{2}{*}{ Model } & \multicolumn{2}{|c|}{$\begin{array}{c}\text { Unstandardized } \\
\text { Coefficients }\end{array}$} & \multirow{2}{*}{$\begin{array}{c}\text { Standardized } \\
\text { Coefficients } \\
\text { Beta }\end{array}$} & \multirow{2}{*}{$\begin{array}{c}\mathbf{t} \\
\text { Tolerance }\end{array}$} & \multirow{2}{*}{$\begin{array}{l}\text { Sig. } \\
\text { VIF }\end{array}$} & \multicolumn{2}{|c|}{$\begin{array}{c}\text { Collinearity } \\
\text { Statistics }\end{array}$} \\
\hline & B & Std. Error & & & & B & Std. Error \\
\hline 1 (Constant) & 3.225 & .467 & & 6.909 & .000 & & \\
\hline $\mathrm{i} 1 \mathrm{~A}$ & .036 & .069 & .051 & .524 & .602 & .797 & 1.255 \\
\hline Responses to Item 2 & .159 & .061 & .297 & 2.597 & .012 & .585 & 1.710 \\
\hline $\mathrm{i} 3 \mathrm{~A}$ & -.013 & .089 & -.017 & -.148 & .883 & .590 & 1.694 \\
\hline Responses to Item 4 & .217 & .066 & .391 & 3.295 & .002 & .544 & 1.838 \\
\hline Responses to Item 5 & -.012 & .051 & -.028 & -.238 & .813 & .559 & 1.790 \\
\hline Responses to Item 6 & .009 & .063 & .016 & .146 & .884 & .657 & 1.522 \\
\hline Responses to Item 7 & .015 & .050 & .034 & .301 & .765 & .584 & 1.713 \\
\hline Responses to Item 8 & -.142 & .050 & -.283 & -2.825 & .006 & .765 & 1.307 \\
\hline Responses to Item 9 & -.087 & .059 & -.168 & -1.486 & .142 & .600 & 1.667 \\
\hline Responses to Item 10 & -.024 & .057 & -.050 & -.422 & .674 & .538 & 1.858 \\
\hline
\end{tabular}

\section{Key:}

i1A: Unity in Diversity; Item 2: Creativity - Adaptability; Concern

i3A: Culture nurturing Item 4: Customer Care
Item 5: Quality Consciousness Item 6: Collaboration

Item 7: Open Communication Item 8: Code of Conduct
Item 9: Role Clarity Item 10: Employee 


\begin{tabular}{|c|c|c|}
\hline 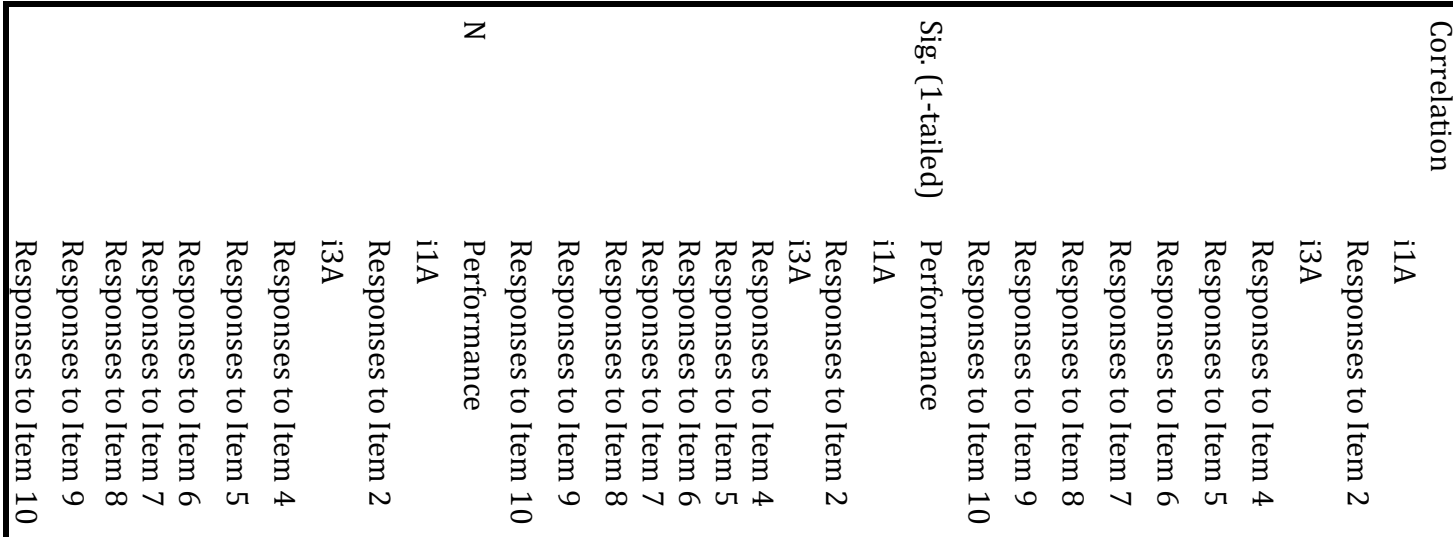 & 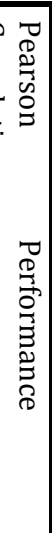 & \\
\hline 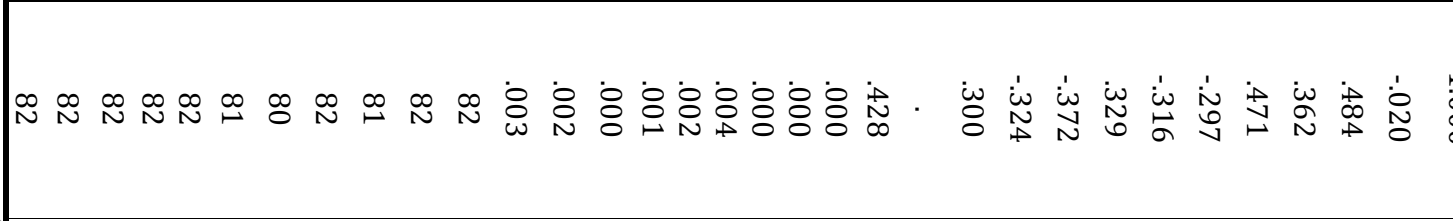 & : & 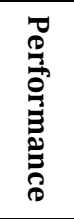 \\
\hline 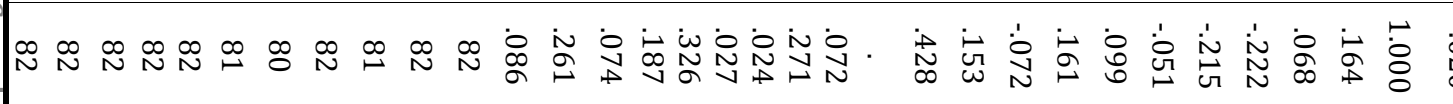 & & $\ddot{\nabla}$ \\
\hline 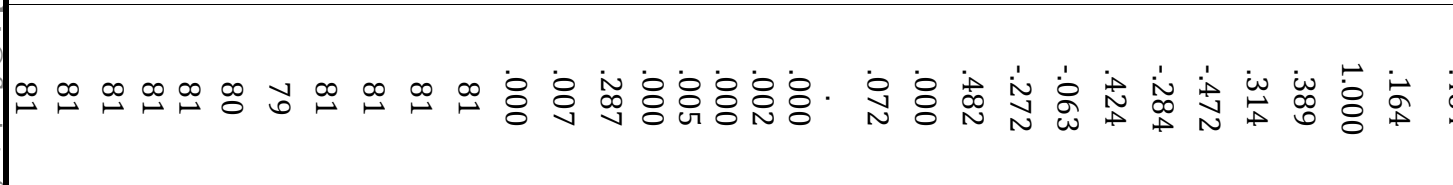 & 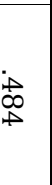 & 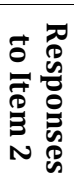 \\
\hline 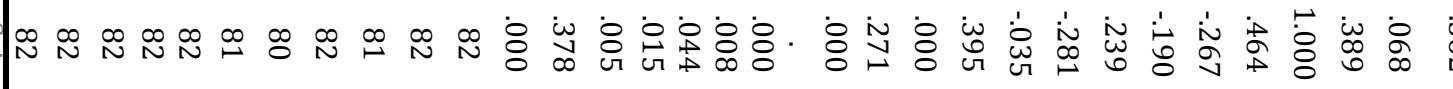 & & $\ddot{\ddot{D}}$ \\
\hline 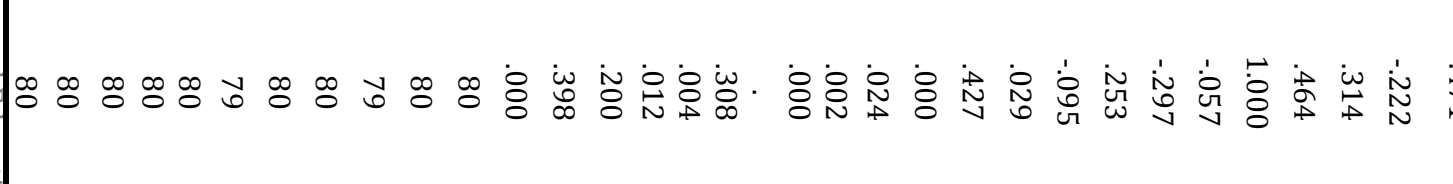 & $\stackrel{\leftrightarrow}{\triangleleft}$ & 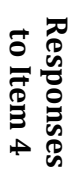 \\
\hline $\mid$ & 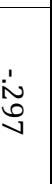 & 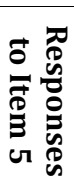 \\
\hline 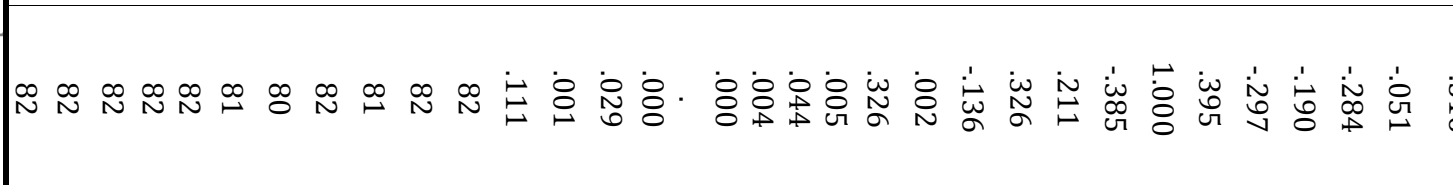 & $\dot{\omega}$ & 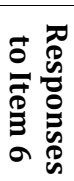 \\
\hline 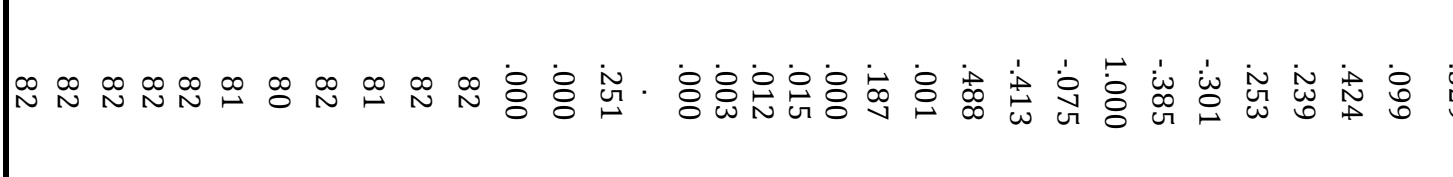 & & 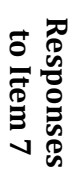 \\
\hline 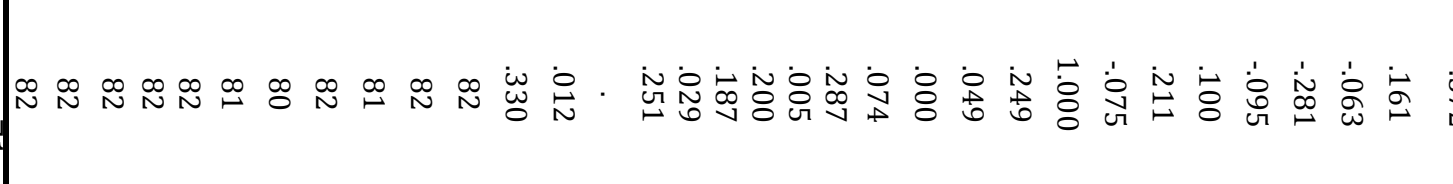 & & 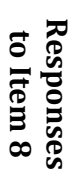 \\
\hline 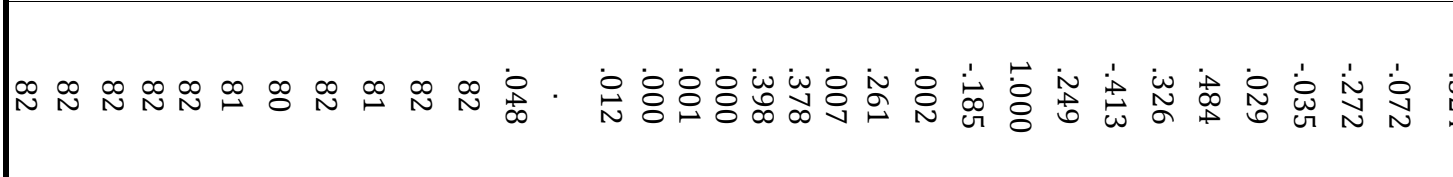 & & 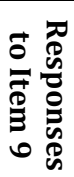 \\
\hline 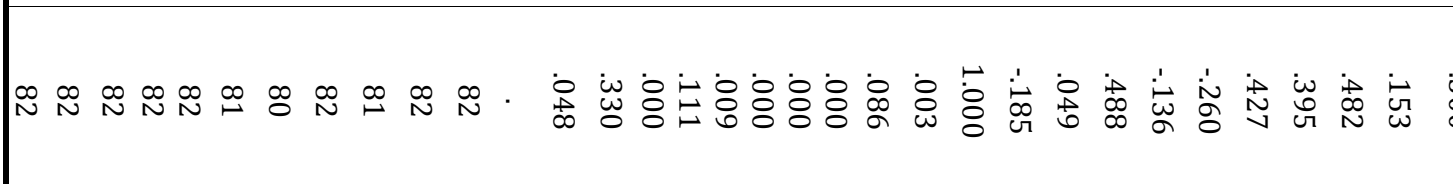 & & 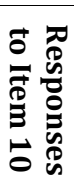 \\
\hline
\end{tabular}


The tables above are the result from multiple regression analysis of the contribution of the cultural elements on performance for Covenant University. In the correlation table (Table 3d), the column showing i1A, responses to item 2, i3A, and responses item 4 to responses to item 10 , represent each of the cultural element analyzed for Covenant University. From the analysis in table 4.13, items 2, i3A, 4, 6, 7, 8, 9 and 10, have moderately strong correlations with the dependent variable (Performance), which is equal to and above ".300". Also, the correlation among each of the independent variables is not too high; therefore, we retain all the independent variables for further analysis.

In table 3a (model summary), the result shows ".480" in the ' $R$ ' square column, which means that our model (the cultural elements) explains $48.0 \%$ of the variance on performances of Covenant University, meaning it is a weak relationship.

In the "Beta" column of table 3c (coefficient table), the largest value is considered, that is ".391" for item 4. This means that, the cultural element item 4 makes the strongest unique contribution on the dependent variable (Performance). The Beta values for the other elements indicate that they made less contribution on performance. The "Sig." column of the same table 4.12 reflects that items 2,4 , and 8 , made a statistically significant unique contribution on performances of Covenant University.

The analysis below is a multiple regression analysis on Olabisi Onabanjo University:

Table 4a: Model Summary for Olabisi Onabanjo University (OOU)

\begin{tabular}{|c|c|c|c|c|}
\hline Model & R & R Square & $\begin{array}{c}\text { Adjusted } \\
\text { R Square }\end{array}$ & $\begin{array}{c}\text { Std. Error of } \\
\text { the } \\
\text { Estimate }\end{array}$ \\
\hline 1 & $.648(\mathrm{a})$ & .420 & .333 & .56028 \\
\hline
\end{tabular}

Table 4b: ANOVA for Olabisi Onabanjo University (OOU)

\begin{tabular}{|cc|c|c|c|c|c|}
\hline Model & & $\begin{array}{c}\text { Sum of } \\
\text { Squares }\end{array}$ & df & $\begin{array}{c}\text { Mean } \\
\text { Square }\end{array}$ & F & Sig. \\
\hline 1 & Regression & 15.227 & 10 & 1.523 & 4.851 & $.000(\mathrm{a})$ \\
& Residual & 21.032 & 67 & .314 & & \\
& Total & 36.260 & 77 & & & \\
\hline
\end{tabular}


Table 4c: Coefficients for Olabisi Onabanjo University (OOU)

\begin{tabular}{|c|c|c|c|c|c|c|c|c|}
\hline \multicolumn{2}{|c|}{ Model } & \multicolumn{2}{|c|}{$\begin{array}{l}\text { Unstandardized } \\
\text { Coefficients }\end{array}$} & \multirow{2}{*}{$\begin{array}{c}\text { Standardized } \\
\text { Coefficients } \\
\text { Beta } \\
\end{array}$} & \multirow{2}{*}{$\begin{array}{c}\mathbf{t} \\
\text { Tolerance } \\
\end{array}$} & \multirow{2}{*}{$\begin{array}{l}\text { Sig. } \\
\text { VIF }\end{array}$} & \multicolumn{2}{|c|}{$\begin{array}{c}\text { Collinearity } \\
\text { Statistics }\end{array}$} \\
\hline & & B & Std. Error & & & & B & $\begin{array}{l}\text { Std. } \\
\text { Error }\end{array}$ \\
\hline \multirow[t]{11}{*}{1} & (Constant) & 4.584 & .564 & & 8.133 & .000 & & \\
\hline & $\mathrm{i} 1 \mathrm{~A}$ & -.219 & .090 & -.260 & -2.447 & .017 & .770 & 1.299 \\
\hline & Responses to Item 2 & -.066 & .064 & -.121 & -1.032 & .306 & .630 & 1.588 \\
\hline & $\mathrm{i} 3 \mathrm{~A}$ & .056 & .093 & .072 & .604 & .548 & .609 & 1.642 \\
\hline & Responses to Item 4 & .065 & .065 & .103 & 1.007 & .318 & .824 & 1.213 \\
\hline & Responses to Item 5 & -.119 & .062 & -.201 & -1.931 & .058 & .798 & 1.253 \\
\hline & Responses to Item 6 & -.065 & .067 & -.108 & -.968 & .336 & .700 & 1.428 \\
\hline & Responses to Item 7 & -.085 & .059 & -.147 & -1.439 & .155 & .834 & 1.199 \\
\hline & Responses to Item 8 & -.010 & .081 & -.015 & -.118 & .907 & .530 & 1.886 \\
\hline & Responses to Item 9 & -.098 & .080 & -.161 & -1.229 & .223 & .505 & 1.981 \\
\hline & Responses to Item 10 & .201 & .061 & .351 & 3.308 & .002 & .768 & 1.302 \\
\hline
\end{tabular}

Key:

i1A: Unity in Diversity;

Item 2: Creativity - Adaptability;

Concern

i3A: Culture nurturing

Item 4: Customer Care
Item 5: Quality Consciousness Item 6: Collaboration

Item 7: Open Communication Item 8: Code of Conduct
Item 9: Role Clarity

Item 10: Employee 


\begin{tabular}{|c|c|}
\hline 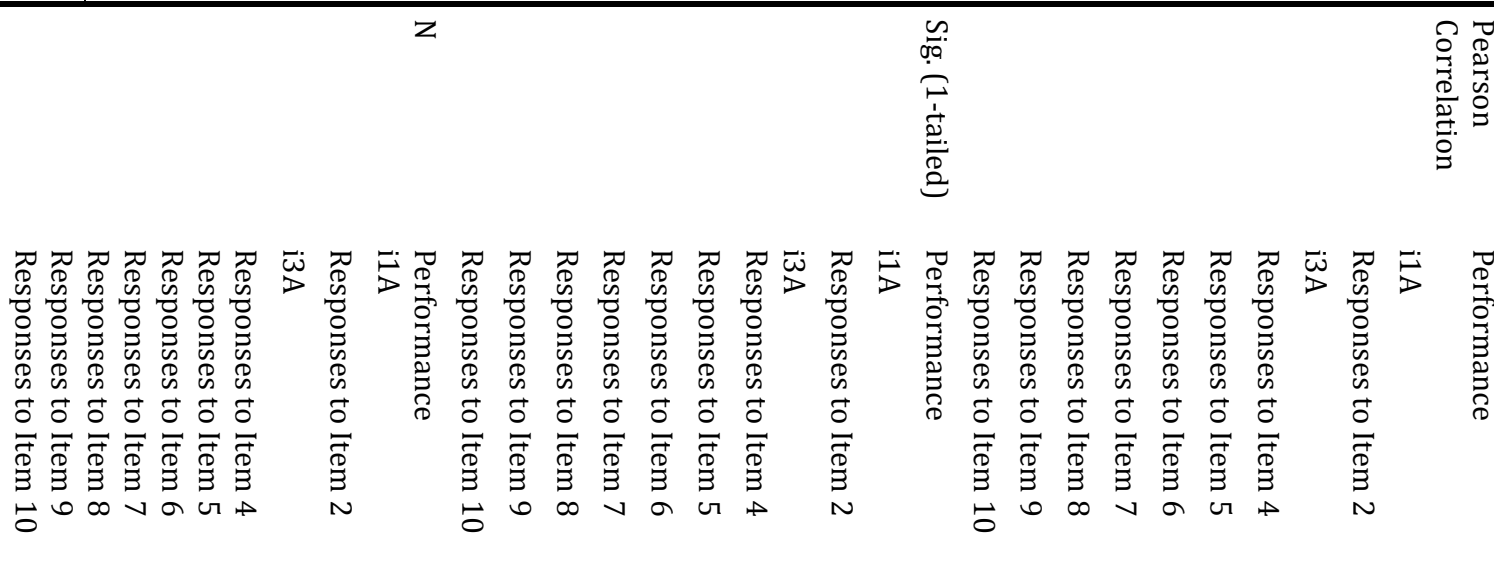 & \\
\hline 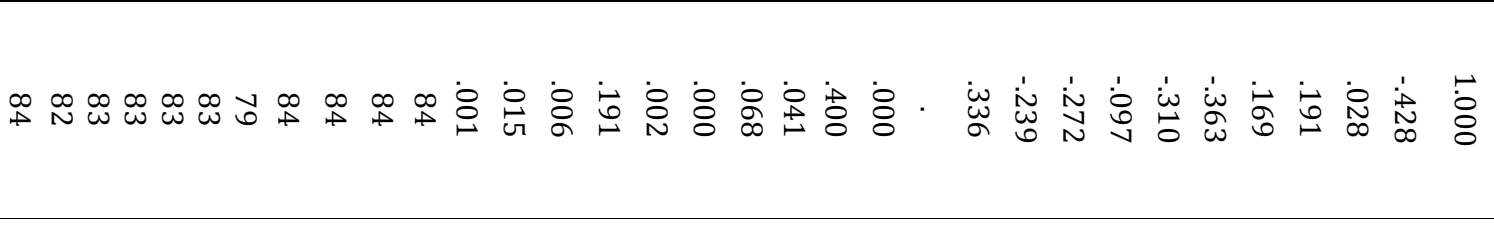 & 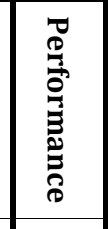 \\
\hline 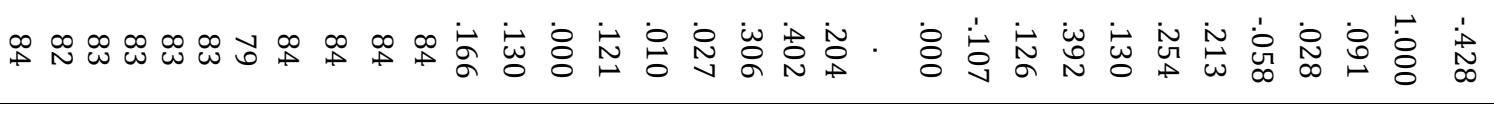 & $\bar{B}$ \\
\hline 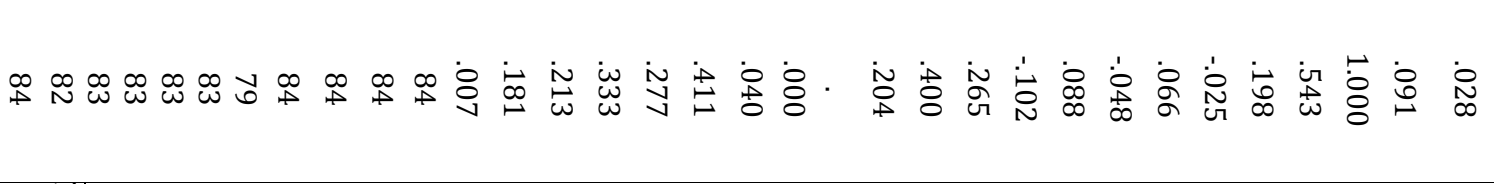 & 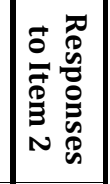 \\
\hline 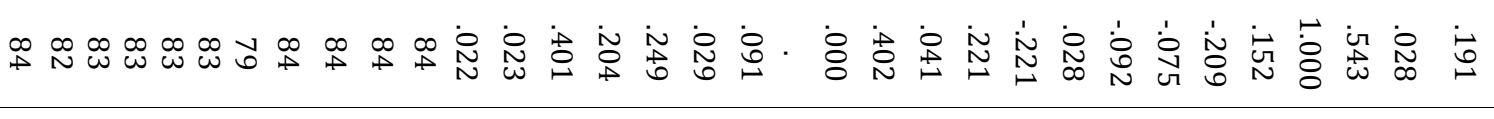 & $\underset{\triangleright}{\varpi}$ \\
\hline 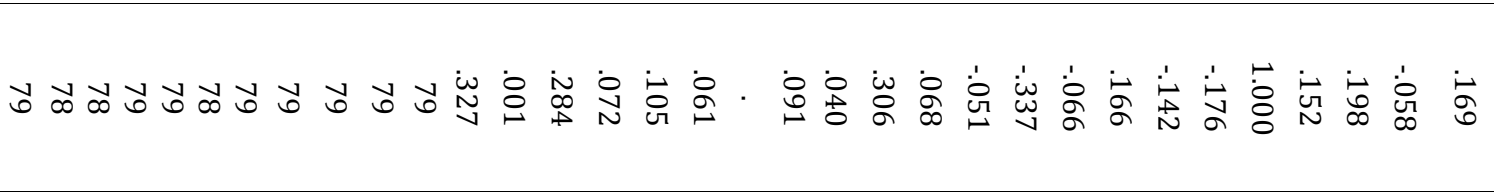 & 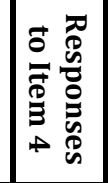 \\
\hline 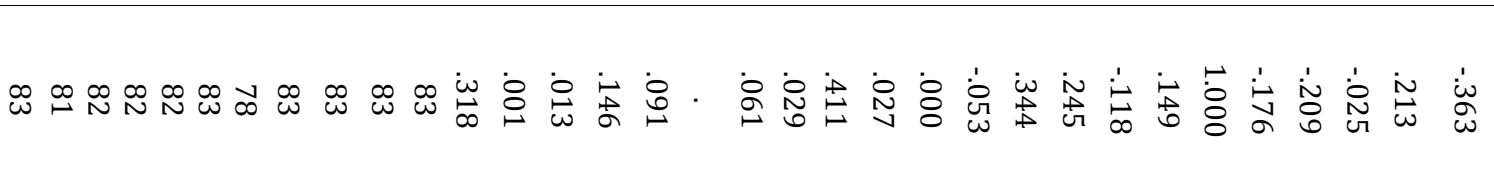 & 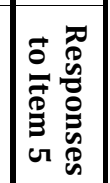 \\
\hline 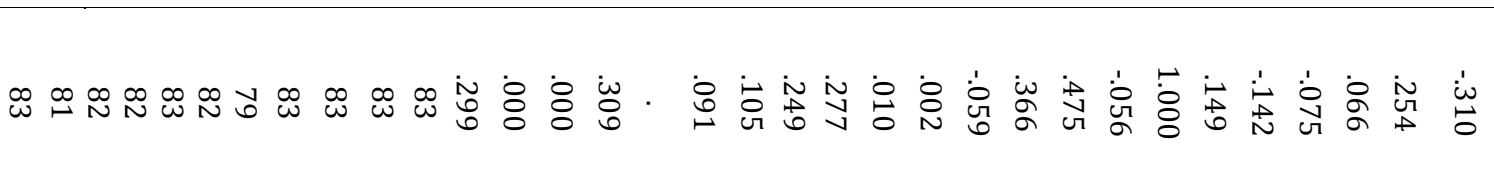 & 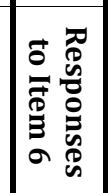 \\
\hline 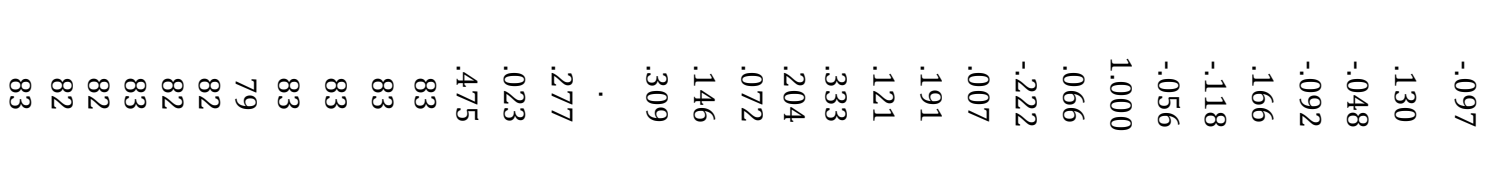 & 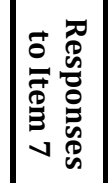 \\
\hline 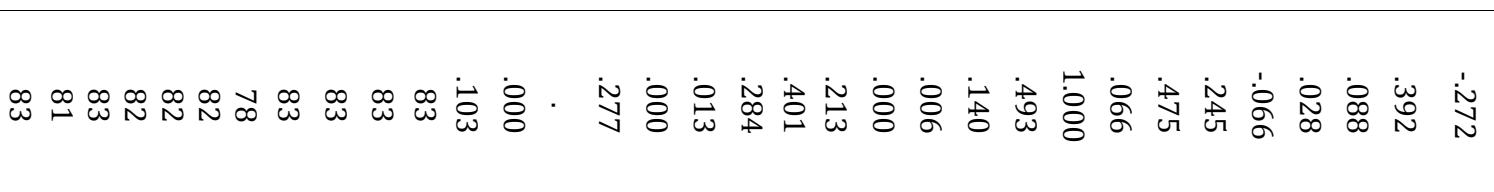 & 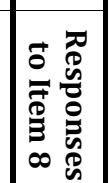 \\
\hline 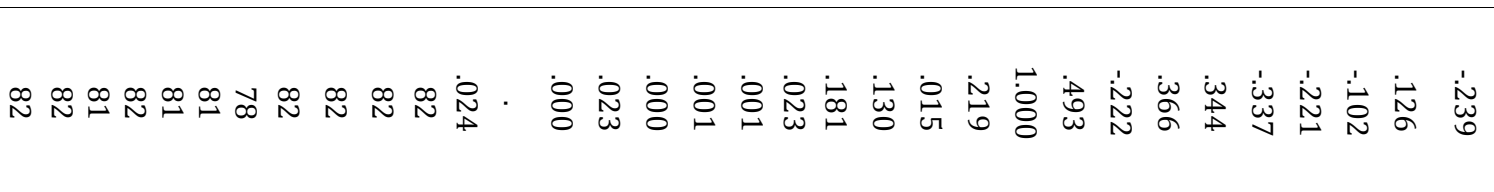 & 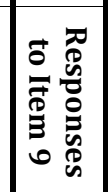 \\
\hline 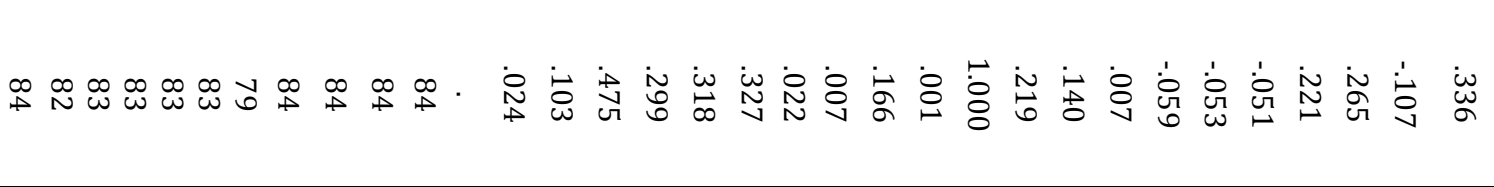 & 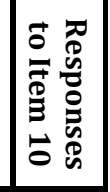 \\
\hline
\end{tabular}


From the analysis above, the contribution of the cultural elements on performance for Olabisi Onabanjo University (OOU) as reflected in the correlation table (Table 4.17) shows that items i1A, 5, 6, and 10, have moderately strong correlations with the dependent variable (Performance), which is equal to and above ".300". Also, the correlation among each of the independent variables is also not too high; therefore, we retain all the independent variables for further analysis.

In table 4.14 (model summary), the result shows ".420" in the ' $R$ ' square column, which means that our model (the cultural elements) explains $42.0 \%$ of the variance on performances of Olabisi Onabanjo University reflecting a weak relationship.

In the "Beta" column of table 4.16 (coefficient table), the largest value is considered, that is ".351" for item 10 meaning that, the cultural element item 10 makes the strongest unique contribution on the dependent variable (Performance). The Beta values for the other elements indicate that they made less contribution on performance. The "Sig." column of the same table 4.12 reflects that items 1 , and 10 , made a statistically significant unique contribution on performances of Covenant University.

The analysis below is a multiple regression analysis on University of Agriculture:

Table 5a: Model Summary for University of Agriculture

\begin{tabular}{|c|c|c|c|c|}
\hline Model & R & R Square & $\begin{array}{c}\text { Adjusted } \\
\text { R Square }\end{array}$ & $\begin{array}{c}\text { Std. Error of } \\
\text { the } \\
\text { Estimate }\end{array}$ \\
\hline 1 & $.818(\mathrm{a})$ & .669 & .618 & .34835 \\
\hline
\end{tabular}

Table 5b: ANOVA for University of Agriculture

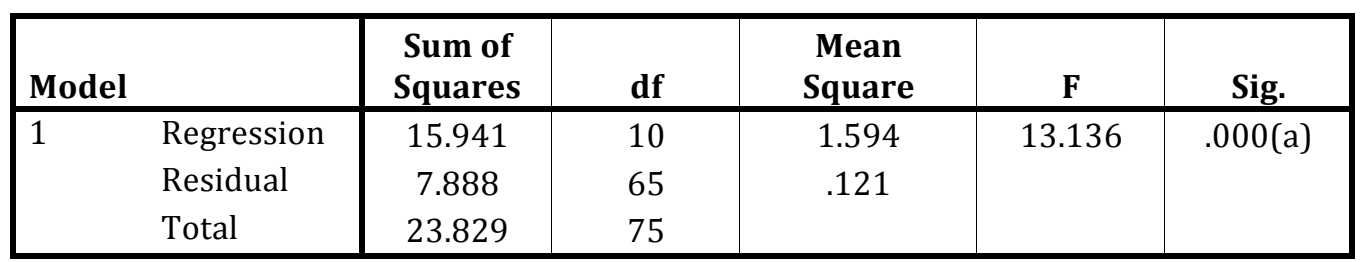


Ibidunni, O. S., \& Mayowa, A. G. (2014). Predicting Performance through the Elements of Organizational Culture. Archives of Business Research, 2(6), 62-82

Table 5c: Coefficients for University of Agriculture

\begin{tabular}{|c|c|c|c|c|c|c|c|c|}
\hline & \multirow{2}{*}{ Model } & \multicolumn{2}{|c|}{$\begin{array}{l}\text { Unstandardized } \\
\text { Coefficients }\end{array}$} & \multirow{2}{*}{$\begin{array}{c}\text { Standardized } \\
\text { Coefficients } \\
\text { Beta }\end{array}$} & \multirow{2}{*}{$\begin{array}{c}\text { t } \\
\text { Toleranc } \\
\text { e }\end{array}$} & \multirow{2}{*}{$\begin{array}{l}\text { Sig. } \\
\text { VIF }\end{array}$} & \multicolumn{2}{|c|}{ Collinearity Statistics } \\
\hline & & B & Std. Error & & & & B & Std. Error \\
\hline \multirow[t]{11}{*}{1} & (Constant) & 3.512 & .554 & & 6.339 & .000 & & \\
\hline & i1A & 183 & .053 & .313 & 3.457 & .001 & .622 & 1.607 \\
\hline & Responses to Item 2 & 015 & .055 & .025 & .275 & .784 & 627 & 1.596 \\
\hline & $\mathrm{i} 3 \mathrm{~A}$ & -.071 & .102 & -.058 & -.698 & .488 & .735 & 1.360 \\
\hline & Responses to Item 4 & .114 & .042 & .222 & 2.746 & .008 & .777 & 1.286 \\
\hline & Responses to Item 5 & -.185 & .051 & -.441 & -3.653 & .001 & .349 & 2.867 \\
\hline & Responses to Item 6 & .029 & .055 & .057 & .521 & .604 & 422 & 2.369 \\
\hline & Responses to Item 7 & .008 & .042 & .017 & 187 & .852 & .616 & 1.622 \\
\hline & Responses to Item 8 & .015 & .048 & .031 & .316 & .753 & .537 & 1.864 \\
\hline & Responses to Item 9 & -.125 & .035 & -.294 & -3.537 & .001 & .736 & 1.359 \\
\hline & Responses to Item 10 & .106 & .046 & .218 & 2.290 & .025 & .559 & 1.787 \\
\hline
\end{tabular}

Key:

i1A: Unity in Diversity; Item 2:Creativity - Adaptability; Concern

i3A: Culture nurturing Item 4: Customer Care
Item 5: Quality Consciousness Item 6: Collaboration

Item 7: Open Communication Item 8: Code of Conduct
Item 9: Role Clarity

Item 10: Employee 


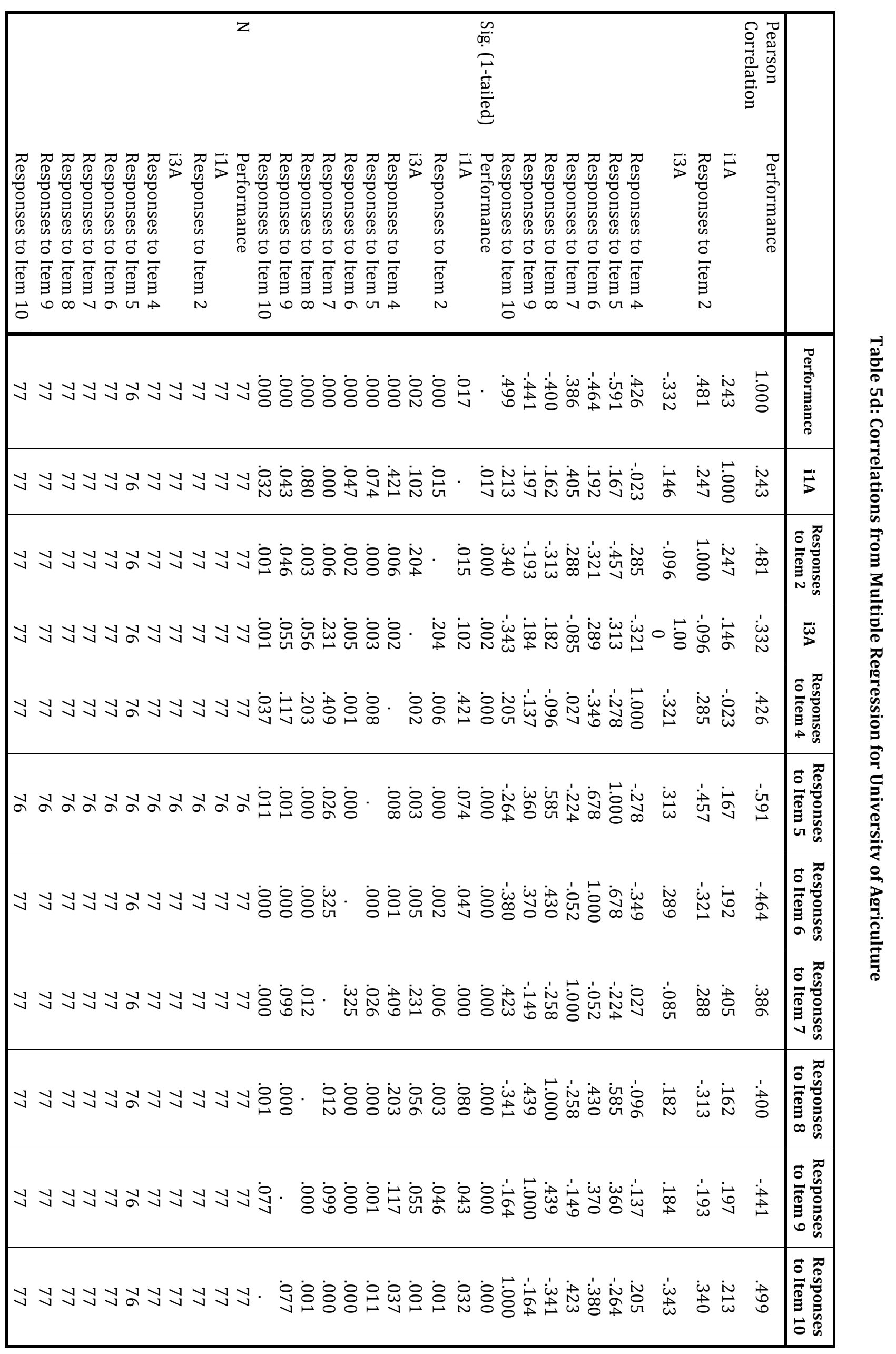


From the analysis above for University of Agriculture (UNAAB), the correlation table (Table 4.21) shows that items 2 , i3A, 4, 5, 6, 7, 8, 9, and 10, have moderately strong correlations with the dependent variable (Performance), which is equal to and above ".300". Also, the correlation among each of the independent variables is also not too high; therefore, we retain all the independent variables for further analysis.

In table 4.18 (model summary), the result shows ".669" in the ' $R$ ' square column, which means that the model (the cultural elements) explains $66.9 \%$ of the variances on performances of University of Agriculture revealing a strong relationship.

In the "Beta" column of table 4.20 (coefficient table), the largest value is considered, that is ".441 " (ignoring the negative sign) for item 5 meaning that, the cultural element item 5 makes the strongest unique contribution on the dependent variable (Performance). The Beta values for the other elements indicate that they made less contribution on performance. The "Sig." column of the same table 4.20 reflects that items $1,4,5,9$, and 10 , made a statistically significant unique contribution on performances of University of Agriculture.

The analysis below is a multiple regression analysis on Public University:

Table 6a: Model Summary for Public Universities

\begin{tabular}{|c|c|c|c|c|}
\hline Model & R & R Square & $\begin{array}{c}\text { Adjusted } \\
\text { R Square }\end{array}$ & $\begin{array}{c}\text { Std. Error of } \\
\text { the } \\
\text { Estimate }\end{array}$ \\
\hline 1 & $.704(\mathrm{a})$ & .496 & .460 & .50864 \\
\hline
\end{tabular}

Table 6b: ANOVA for Public Universities

\begin{tabular}{|cc|c|c|c|c|c|}
\hline Model & & $\begin{array}{c}\text { Sum of } \\
\text { Squares }\end{array}$ & df & $\begin{array}{c}\text { Mean } \\
\text { Square }\end{array}$ & F & Sig. \\
\hline 1 & Regression & 36.359 & 10 & 3.636 & 14.053 & $.000(\mathrm{a})$ \\
& Residual & 36.997 & 143 & .259 & & \\
& Total & 73.355 & 153 & & & \\
\hline
\end{tabular}


Table 6c: Coefficients for Public Universities

\begin{tabular}{|c|c|c|c|c|c|c|c|c|}
\hline \multicolumn{2}{|c|}{ Model } & \multicolumn{2}{|c|}{$\begin{array}{l}\text { Unstandardized } \\
\text { Coefficients }\end{array}$} & \multirow{2}{*}{$\begin{array}{c}\text { Standardized } \\
\text { Coefficients } \\
\text { Beta }\end{array}$} & \multirow{2}{*}{$\begin{array}{c}\mathbf{t} \\
\text { Tolerance }\end{array}$} & \multirow{2}{*}{$\begin{array}{l}\text { Sig. } \\
\text { VIF }\end{array}$} & \multicolumn{2}{|c|}{$\begin{array}{c}\text { Collinearity } \\
\text { Statistics }\end{array}$} \\
\hline & & B & Std. Error & & & & B & $\begin{array}{l}\text { Std. } \\
\text { Error }\end{array}$ \\
\hline \multirow[t]{11}{*}{1} & (Constant) & 3.574 & .338 & & 10.583 & .000 & & \\
\hline & $\mathrm{i} 1 \mathrm{~A}$ & .024 & .052 & .032 & .469 & .640 & .749 & 1.335 \\
\hline & Responses to Item 2 & -.028 & .045 & -.049 & -.626 & .533 & .585 & 1.709 \\
\hline & $\mathrm{i} 3 \mathrm{~A}$ & .050 & .063 & .054 & .798 & .426 & .762 & 1.313 \\
\hline & Responses to Item 4 & .104 & .040 & .175 & 2.619 & .010 & .791 & 1.265 \\
\hline & Responses to Item 5 & -.154 & .039 & -.299 & -3.963 & .000 & .619 & 1.615 \\
\hline & Responses to Item 6 & -.010 & .042 & -.017 & -.239 & .812 & .733 & 1.364 \\
\hline & Responses to Item 7 & -.031 & .039 & -.055 & -.808 & .420 & .753 & 1.327 \\
\hline & Responses to Item 8 & -.055 & .046 & -.091 & -1.199 & .233 & .611 & 1.635 \\
\hline & Responses to Item 9 & -.089 & .041 & -.160 & -2.161 & .032 & .641 & 1.561 \\
\hline & Responses to Item 10 & .204 & .038 & .369 & 5.425 & .000 & .760 & 1.315 \\
\hline
\end{tabular}

\author{
Key: \\ i1A: Unity in Diversity; \\ Item 2: Creativity - Adaptability; \\ Concern \\ i3A: Culture nurturing \\ Item 4: Customer Care
}

Item 5: Quality Consciousness

Item 6: Collaboration

Item 7: Open Communication

Item 8: Code of Conduct
Item 9: Role Clarity

Item 10: Employee

From the analysis above for Public Universities, the multiple regression analysis table (Table 6d) shows that items 2, 4, 5, 8, 9 and 10, have moderately strong correlations with the dependent variable (Performance), which is equal to and above ".300". Also, the correlation among each of the independent variables is also not too high; therefore, we retain all the independent variables for further analysis.

In table 6a (model summary), the result shows ".496" in the ' $R$ ' square column, which means that the model (the cultural elements) explains $49.6 \%$ of the variances on performances of Public Universities revealing a moderate relationship.

In the "Beta" column of table 6c (coefficient table), the largest value is ".369" for item 10 meaning that, the cultural element item 10 makes the strongest unique contribution on the dependent variable (Performance). The Beta values for the other elements indicate that they made less contribution on performance. The "Sig." column of the same table 4.24 reflects that items 4, 5, 9, and 10, made a statistically significant unique contribution on performances of Public Universities.

Based on the above analysis therefore, we shall reject the null hypothesis $\left(\mathrm{H}_{0}\right)$ stating that "there is no significant contribution of elements of organizational culture in predicting the performances of Universities" and accept the alternate hypothesis $\left(\mathrm{H}_{1}\right)$ stating that "there is significant contribution of organization cultural elements on performances of Universities."

\section{CONCLUSION}

Shani et al (2005) concluded that organizational cultures can have a significant impact on an organization's long term economic performance; organizational cultures will probably be an 
even more important factor in determining the success of failure of organizations in the next decade; organizational cultures that inhibit strong long-term financial performance are not rare, they develop easily, even in organizations that are full of reasonable and intelligent people, and; although tough to change, organizational cultures can be made more performance enhancing.

A recent perspective of Rollinson (2005) was firmly part of what is now known as the 'excellence movement', which holds that culture is a key ingredient in the commercial success of an organization. Because authors list cultural characteristics that are said to lead to this outcome of success, it is easy to see why the ideas have an instant appeal to managers.

The challenge, however, is that this perspective and others like it imply a 'one best culture' suitable for all organizations. Since different organizations face different circumstances, the most useful approach to the culture-performance relationship is likely to be a contingency perspective; an assumption that there is no such thing as a 'right' or 'best' culture for all organizations. The most appropriate culture for an organization is the one that best helps it cope with the exigencies of its business environment.

Many managers have attempted to revamp their business culture, some by bench marking themselves against their most admired competitors. This offers few insights for those attempting a business turnaround and the task is all the more daunting because culture is not just about 'how we do things', but also about 'what we do'.

\section{References:}

Bola: Business Open Learning Archive. (2001). What is this thing called organisational culture? [Online]. Available: http://sol.brunel.ac.uk/ jarvis/bola/culture/culture.html; cited in Mowat, J. (2002). Corporate Culture, the Herridge Group.

Borgatti, S. P. (1996). Organizational Culture. [Online]. Available: http://www.analytictech.com/mb021/culture1.htm; cited in Mowat, J. (2002). Corporate Culture, the Herridge Group.

DeWitt, D. J. (2001). The Changing Corporate Culture [on-line]. Available: http://www.informanet.com/corpculture.htm; cited in Mowat, J. (2002). Corporate Culture, the Herridge Group.

Goll, I., \& Zeitz, G. (1991). Conceptualizing and measuring corporate ideology. Organization Studies, 12, 191207; cited in Delobbe, N., Haccoun, R. R. and Vandenberghe, C. Measuring Core Dimensions of Organizational Culture: A Review of Research and Development of a New Instrument.

Gundry, L.K., \& Rousseau, D.M. (1994). Critical incidents in communicating culture to newcomers: The meaning is the message. Human Relations, 47, 1063-1088; cited in Delobbe, N., Haccoun, R. R. and Vandenberghe, C. Measuring Core Dimensions of Organizational Culture: A Review of Research and Development of a New Instrument.

Hagberg, R. and Heifetz, J. (2000). Corporate Culture /Organizational Culture: Understanding and Assessment. [Online]. Available: http://www.hcgnet.com/html/articles/understanding-Culture/html; cited in Mowat, J. (2002). Corporate Culture, The Herridge Group.

Hatch, M. J. (1993). The Dynamics Of Organizational Culture, Academy Of Management Review, 18,Pp.657693; cited in Koteswara, P. K., Srinivasan, P. T. and George J.P. (2002). A study on Development of a Tool to Assess Organizational Culture in Indian Organizations, India, Available [online] http://www.google.com

Koberg, C.S., \& Chusmir, L.H. (1987). Organizational culture relationships with creativity and other job-related variables. Journal of Business Research, 15, 397-409; cited in Delobbe, N., Haccoun, R. R. and Vandenberghe, C. 
Measuring Core Dimensions of Organizational Culture: A Review of Research and Development of a New Instrument.

Koteswara, P. K., Srinivasan, P. T. and George J.P. (2002). A study on Development of a Tool to Assess Organizational Culture in Indian Organizations, India, Available [online] http://www.google.com

McShane, S. L. and Von Glinow M. A. (2005) Organizational Behaviour, Boston, McGraw Hill/Irwin, (3rd Edition)

Mowat, J. (2002) Corporate Culture, the Herridge Group. Retrieved from www.herridgegroup.com/pdfs/corp_cultures.pdf

O'Reilly, C.A., Chatman, J., \& Caldwell, D. (1991). People and organizational culture: A profile comparison approach to assessing person-organization fit. Academy of Management Journal, 34, 487-516; cited in Delobbe, N., Haccoun, R. R. and Vandenberghe, C. Measuring Core Dimensions of Organizational Culture: A Review of Research and Development of a New Instrument.

Rollinson, D. (2005). Organizational Behaviour and Analysis: An Integrated Approach, England, Pearson Education, (3rd Edition)

Shani, A. B. and Lau, J. B. (2005). Behaviour in Organizations: An Experiential Approach, USA, McGraw Hill Irwin, (8th Edition) 


\begin{tabular}{|c|c|}
\hline 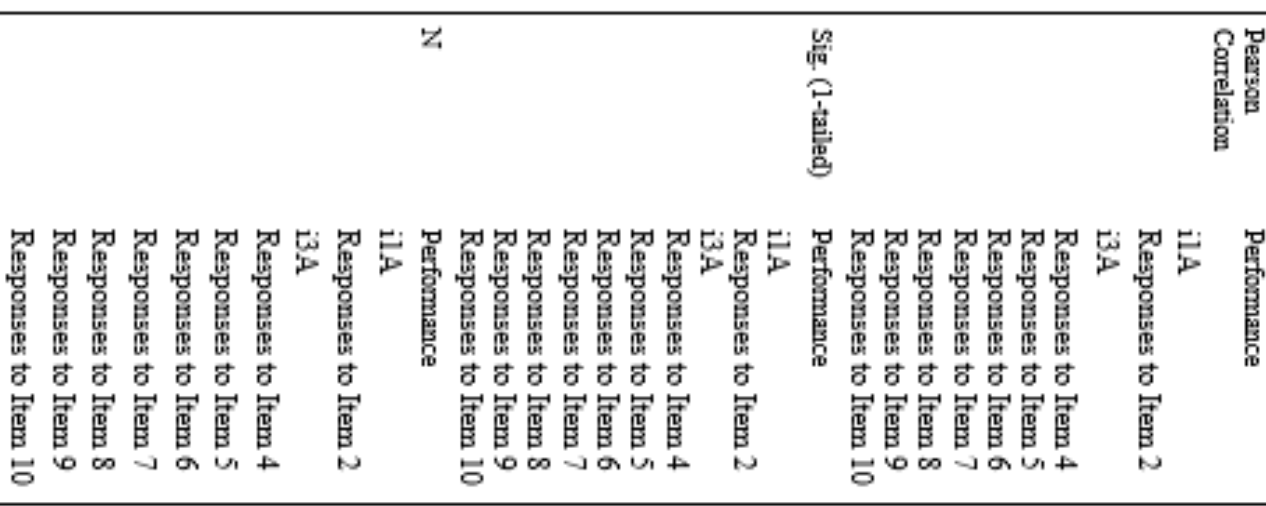 & \\
\hline 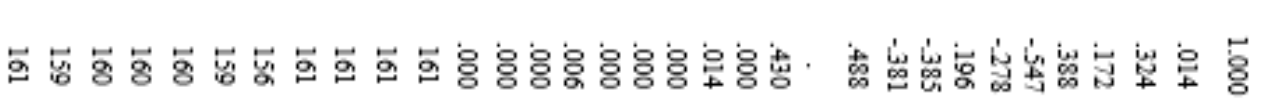 & \\
\hline 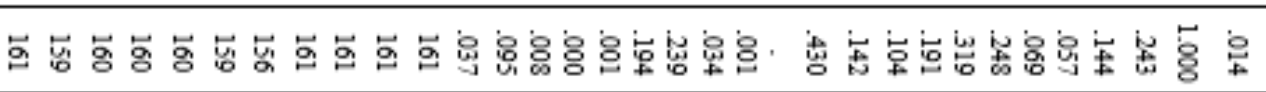 & 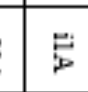 \\
\hline 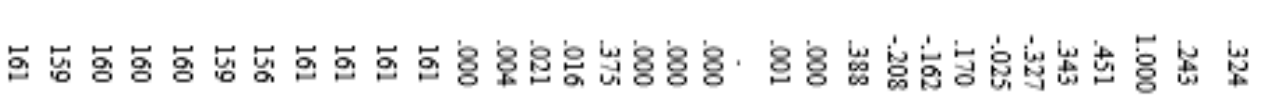 & 总触 \\
\hline 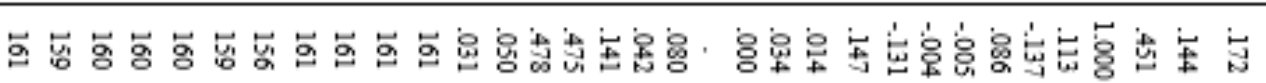 & \\
\hline 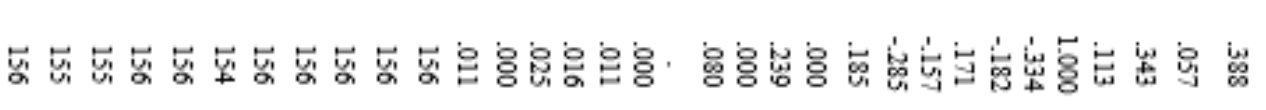 & 总兽 \\
\hline 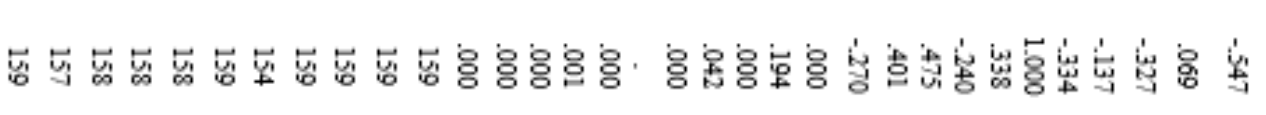 & 总覞 \\
\hline 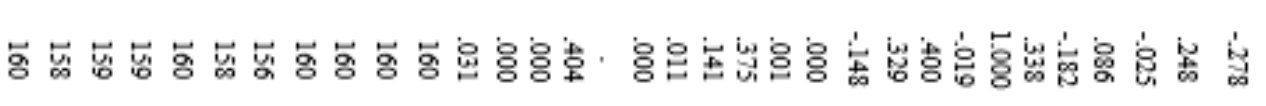 & 5 \\
\hline 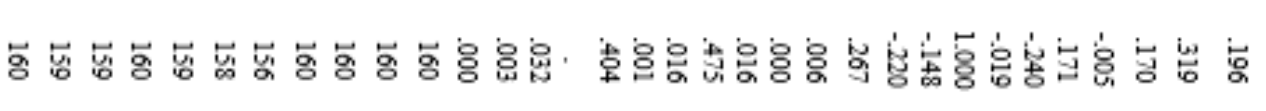 & 羁 \\
\hline 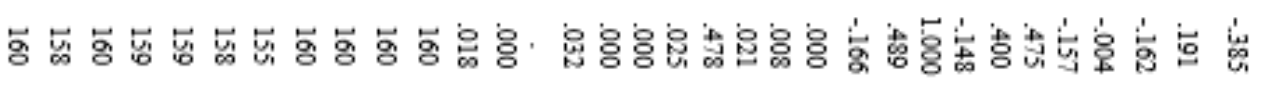 & 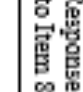 \\
\hline 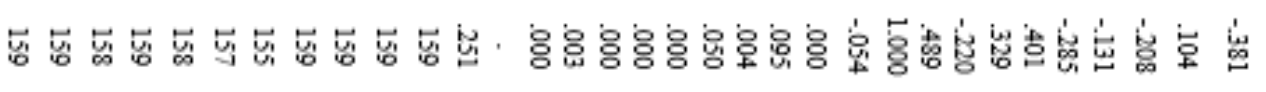 & 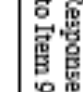 \\
\hline - & \\
\hline
\end{tabular}

